\title{
Influence of the conservation condition on the germination of mandacaru seeds from the Caatinga and Atlantic Forest areas
}

\author{
Vitor Araujo Targino ${ }^{1}{ }^{\circ}$, Gilvaneide Alves de Azerêdo ${ }^{1} \mathbb{\oplus}$, \\ João Henrique Constantino Sales Silva ${ }^{1 *} \mathbb{D}$, Vênia Camelo de Souza ${ }^{1}[0$ \\ 1 Universidade Federal da Paraíba, Centro de Ciências Humanas, Sociais e Agrárias, Bananeiras, PB, Brasil. E-mail: vitoraraujo2204@gmail.com; azeredogil@yahoo.com.br; \\ joaohenriqueconst@gmail.com; venia_camelo@hotmail.com
}

ABSTRACT: Due to the wide distribution and the constant threat and degradation to which the cactacies of the Caatinga and Atlantic Forest biomes are subjected, strategies for the conservation of native species belonging to this group of plants become urgent and necessary. Therefore, the study aimed to evaluate the physiological quality of mandacaru seeds under different conservation conditions during storage. The seeds were stored for a period of twelve months, comprising the 0 (control), 2, 4, 6, 8, and 12 months in two conservation conditions (10 \pm 1 and $24 \pm 2{ }^{\circ} \mathrm{C}$ ), two packages (paper and glass), and two collection areas (Caatinga and Atlantic Forest). The number of germinated seeds was counted daily for 21 days after root protrusion. The evaluated variables were: water content (\%), germination (\%) and germination speed index (GSI). There germination and vigor of mandacaru seeds stored at room temperature decreased over time. The paper packaging was more efficient than the glass container when the seeds were kept at room temperature. The mandacaru seeds, when kept in the refrigerator, had their physiological quality preserved, and this condition is indicated as ideal for the conservation seeds, regardless of the tested packaging.

\section{Influência da condição de conservação sobre a germinação de sementes de mandacaru provenientes de áreas de Caatinga e Mata Atlântica}

RESUMO: Em decorrência da ampla distribuição e da constante ameaça e degradação a que estão sujeitas as cactáceas dos biomas Caatinga e Mata Atlântica, estratégias para a conservação das espécies nativas pertencentes a este grupo de plantas tornam-se urgentes e necessárias. Assim sendo, o estudo teve como objetivo avaliar a qualidade fisiológica de sementes de mandacaru em diferentes condições de conservação durante 0 armazenamento. As sementes foram armazenadas por um período de 0 (controle), 2, 4, 6, 8 e 12 meses em duas condições de conservação ( $10 \pm 1$ e $24 \pm 2{ }^{\circ} \mathrm{C}$ ), duas embalagens (papel e vidro) e duas áreas de coleta (Caatinga e Mata Atlântica). A contagem do número de sementes germinadas foi realizada diariamente durante 21 dias após a protrusão radicular. As variáveis avaliadas foram: teor de água (\%), germinação (\%) e índice de velocidade de germinação (IVG). Houve redução da germinação e do vigor de sementes de mandacaru armazenadas em temperatura ambiente ao longo do tempo. A embalagem de papel foi mais eficiente que o vidro quando as sementes foram conservadas em temperatura ambiente. As sementes de mandacaru, quando conservadas em geladeira, têm sua qualidade fisiológica preservada, sendo esta condição indicada como ideal para a conservação das sementes, independente das embalagens testadas.

Palavras-chave: Cereus jamacaru; longevidade; embalagem; armazenamento; vigor

\footnotetext{
* João Henrique Constantino Sales Silva - E-mail: joaohenriqueconst@gmail.com (Corresponding author)

Associate Editor: Giuseppina Pace Pereira Lima
} 


\section{Introduction}

The Cactaceae family is organized in Brazil by the conjunction of 484 species grouped into 81 genera that are distributed throughout all phytogeographic domains of the country (Zappi \& Taylor, 2020). In Brazil, the vast majority of cacti are found in regions of the Atlantic Forest, Caatinga and Restingas, capoeiras and riparian forests, characterized by having photosynthesizing stems, cladododontium or phyllocladium type, with the ability to store water and nutrients (Gomes, 2014). Due to their economic, ecological and social importance in various ecosystems, cacti are considered priority plants for conservation actions (Menezes \& RibeiroSilva, 2015). About a third of all cactus species in the world are at risk of extinction as a result of anthropic actions and, in Brazil, the family Cactaceae is one of the ten most threatened of the national flora, which makes this scenario an alert for the need to support the conservation of this botanical family (Gomes et al., 2020).

One of the main difficulties for both seed conservation in banks and propagation in cultivation is the little knowledge about the seed biology of native cacti (Silva et al., 2011). Seed storage is a conservation method that aims to preserve the physical and physiological quality of seeds, allowing them to remain viable for long periods and to be used for various purposes, such as studies on genetic, morphological and physiological diversity of the species, formation of germplasm banks and reforestation (Silva et al., 2011). Research related to the conservation, longevity and viability of seeds of cactaceous plants endemic to Brazil are still lacking studies and few data are found in the literature, as exemplified by the works reported by Abud et al. (2012), Abud et al. (2016), Nascimento \& Meiado (2016), Santos et al. (2018) and Silva et al. (2018). However, although papers on the conservation of Cereus jamacaru seeds have been found, they did not involve seeds from different ecosystems and did not evaluate the behavior of the seeds regarding storage for long periods.

The knowledge about the origin of the seeds is also a factor of great importance in storage, since for each population there can be variations among the plants that can present different characteristics. Individuals belonging to the same species but occurring in different ecosystems can show differences in the germination behavior of seeds; these differences in germination response may be related to the genetic inheritance of the specimens or to the different source populations, which are directly influenced by the edaphoclimatic characteristics of the environment where the parental plants are located during the breeding period (Hoppe et al., 2004; Oliveira et al., 2017).

Given the ecological relevance of the mandacaru and also because it is a species with forage and ornamental potential, seed conservation for in situ and ex situ propagation is of utmost importance. Given the limitations of information about the behavior of seeds regarding storage, studies that aim to contribute with basic knowledge about the conservation and perpetuation of the species are of great importance. Therefore, this study aimed to evaluate the physiological quality of stored mandacaru seeds from two ecosystems under different conservation conditions.

\section{Materials and Methods}

\section{Location of the fruit collection areas}

The mandacaru seeds used in this research came from ripe fruits collected in two areas (Figure 1) of natural occurrence
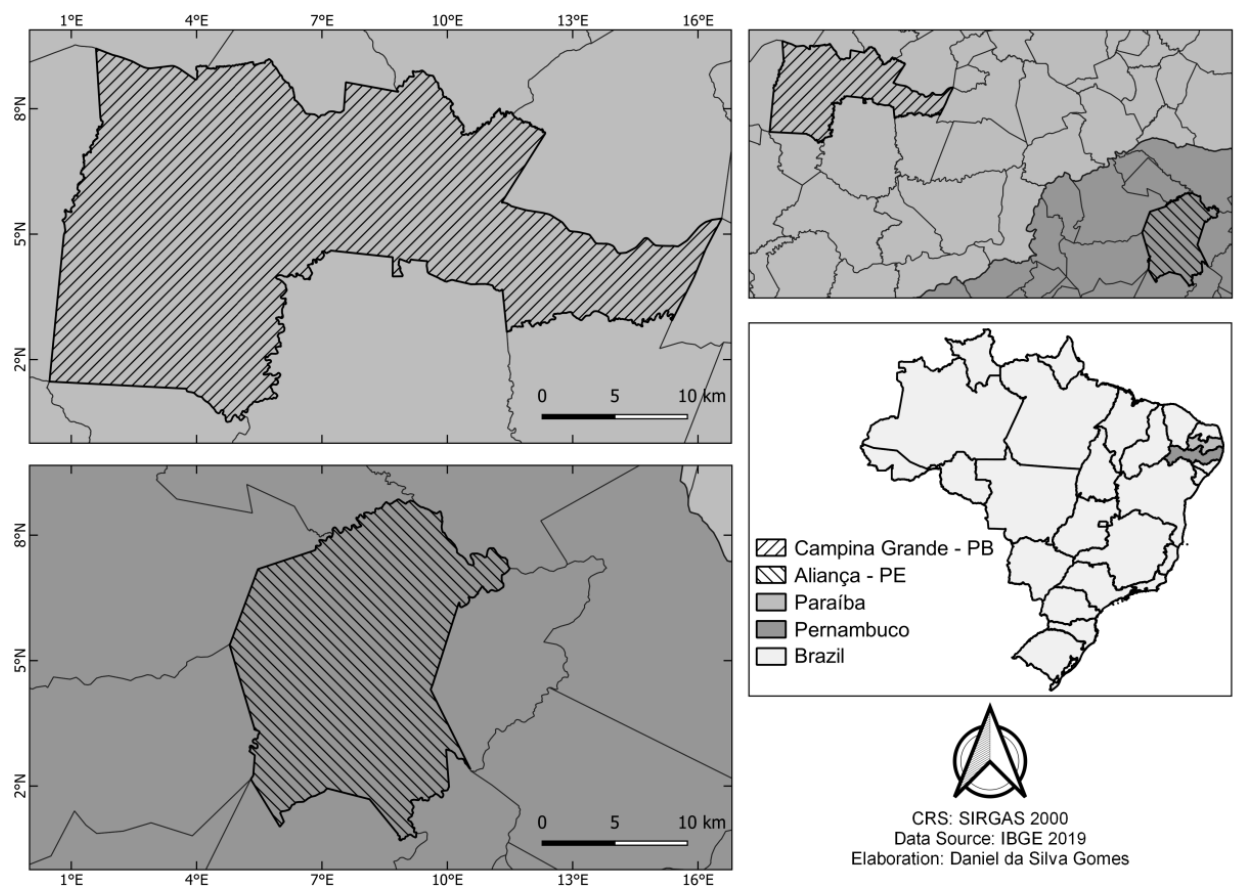

Figure 1. Location of the collection areas of mandacaru fruits, in the municipalities of Campina Grande - Paraíba and Aliança Pernambuco, Brazil. 
of the species: The first is a fragment of preserved Caatinga forest situated in the Instituto Nacional do Semiárido (INSA), located in the municipality of Campina Grande, Paraíba; The second area is a remnant of Atlantic Forest in an advanced state of degradation, located in the municipality of Aliança, Pernambuco. The fruits were collected in the two areas in April 2018, totaling 60 fruits, 30 from the area of Campina Grande Paraíba and 30 from the area of Aliança - Pernambuco.

The municipality of Campina Grande, located in the Mesoregion of Agreste Paraibano ( $7^{\circ} 16^{\prime} 47^{\prime \prime} \mathrm{S}, 35^{\circ} 58^{\prime} 29^{\prime \prime}$ $\mathrm{W})$, has an approximate altitude of $494 \mathrm{~m}$. The municipality is inserted in the geoenvironmental unit of the Planalto da Borborema. The climate classification is As' according to Köppen and Geiger. The location has a temperature between 18 and $30{ }^{\circ} \mathrm{C}$ and an average annual rainfall of 876 $\mathrm{mm}$. The soil in the region is mostly Litholic Neosol, which is characterized by being shallow and stony, associated with rocky outcroppings.

The municipality of Aliança, located in the Mesoregion of Zona da Mata Pernambucana ( $7^{\circ} 36^{\prime} 12^{\prime \prime} \mathrm{S}, 35^{\circ} 13^{\prime} 51^{\prime \prime} \mathrm{W}$ ), is at an altitude of around $123 \mathrm{~m}$. The native vegetation of the region is formed by fragments of Atlantic Forest and the soil is of the type Eutrophic Yellow Red Podzolic Equivalent. The regions climate is classified as As' (rainy tropical), hot and humid (Köppen classification), with temperatures between 22 and $30^{\circ} \mathrm{C}$ and average annual precipitation of $1.200 \mathrm{~mm}$.

\section{Seed processing and storage}

The research was conducted in the Seed Technology Laboratory of the Center for Human, Social and Agrarian Sciences of the Universidade Federal da Paraíba, Campus III, Bananeiras, Paraíba, Brazil. In the laboratory, the fruits were pulped by macerating them in a sieve and then washed in running water. Then, the seeds were homogenized and dried in the shade $\left(24 \pm 2{ }^{\circ} \mathrm{C}\right)$ on the laboratory bench for four days. After this period, the seeds were stored in PET plastic bottles $(250 \mathrm{~mL})$ at room temperature until the experiment was conducted. The seeds, except those from the control group that remained in the plastic bottles, were stored in two packages (paper and glass) and in two environmental conditions: refrigerator $\left(10 \pm 1{ }^{\circ} \mathrm{C} ; 43 \pm 2 \% \mathrm{RH}\right)$ and room temperature $\left(24 \pm 2{ }^{\circ} \mathrm{C} ; 73 \pm 12 \% \mathrm{RH}\right)$, for a period of 2,4 , $6,8,12$ months and the control (0 month). The temperature and relative humidity data (Figure 2 ) were collected with the help of a thermo-hygrometer during the entire experimental period.

\section{Germination test}

The seeds were placed to germinate between "blotting paper", previously sterilized and moistened with distilled water in a volume $(\mathrm{mL})$ equivalent to 2.5 times their dry weight, with two leaves at the base and one over the seeds and kept in a Biochemical Oxygen Demand (BOD) germinator under a constant temperature of $25{ }^{\circ} \mathrm{C}$ and photoperiod of $12 \mathrm{~h}$. This temperature and photoperiod were chosen based on preliminary tests. Four repetitions of 50 seeds were used and distributed in transparent plastic boxes with lids, "gerbox" type, with dimensions $11 \times 11 \times 3.5 \mathrm{~cm}$.

The counting of the number of germinated seeds was performed daily for 21 days, with root protrusion being the criterion adopted to consider the seed as germinated. The variables evaluated were: water content (\%), germination percentage, germination speed index (GSI) - according to the equation proposed by Maguire (1962) and percentage of normal seedlings. The water content of the seeds was determined with two repetitions of approximately 100 seeds each, for all treatments, which were weighed on a $0.0001 \mathrm{~g}$ precision scale and dried using the oven method at $105 \pm 3$ ${ }^{\circ} \mathrm{C}$ for 24 hours. The evaluations were made according to the criteria established by the Rules for Seed Analysis (Brasil, 2009).

\section{Data analysis}

The statistical design used was entirely randomized following the $2 \times 2 \times 6$ factorial scheme (packaging $\times$ preservation conditions $\times$ storage period), for each area,

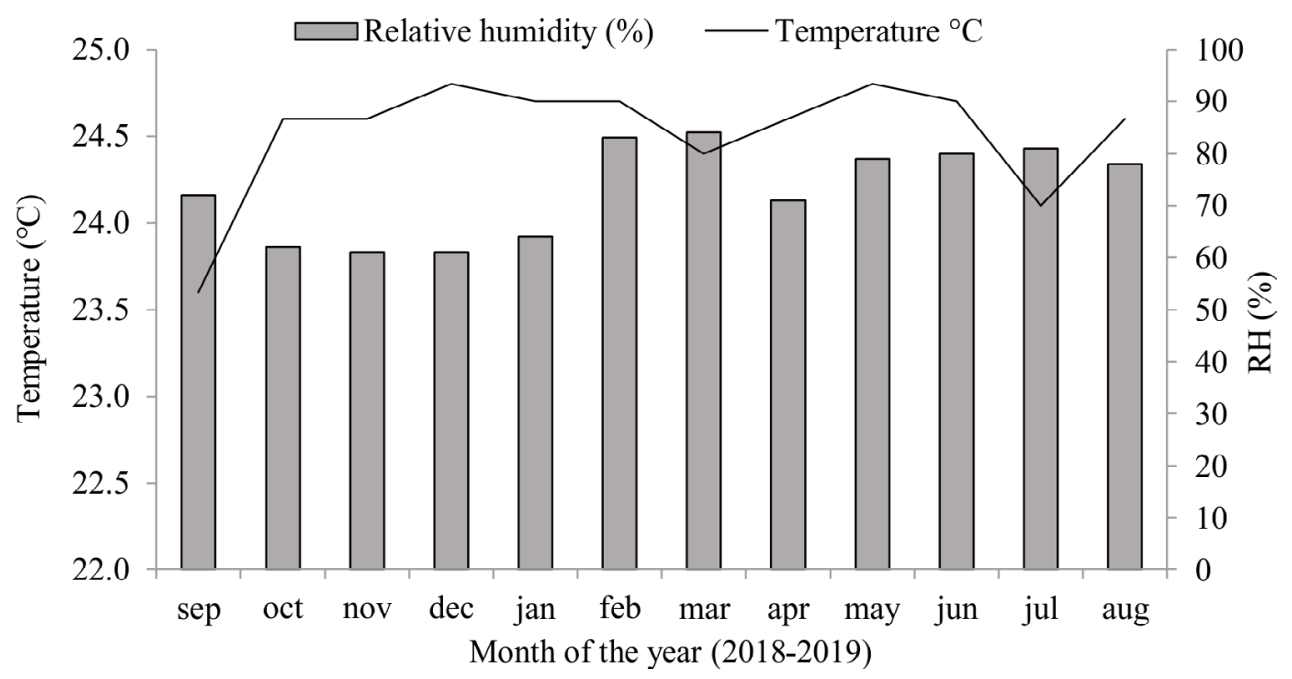

Figure 2. Monthly averages of temperature $\left({ }^{\circ} \mathrm{C}\right)$ and relative humidity $(\%)$ recorded at room temperature in the laboratory from September/2018 to August/2019. 
totaling 24 treatments. The data were submitted to variance analysis according to the Tukey test at $5 \%$ significance level. The statistical analyses were processed in the software ESTAT/ Jaboticabal $^{\circledR}$ and then the databases were assembled in Microcal Origin $6.0^{\circledR}$. Initially, polynomial and linear equations were adjusted, but due to the occurrence of negative estimates for some characteristics, we opted for adjustments according to the methodology used by Pôrto et al. (2006), whose model adopted was the Logistic 1 (Equation 1).

$$
y=\frac{a}{1+e^{-k(x-x c)}}
$$

Where: $y=$ value of the characteristic for a given value of $x$ (storage period); $a=$ maximum value of characteristic $\mathrm{y}$; e = base of the Neperian logarithm; $k$ = relative growth rate (in the present case of $y$ reduction); $x c=$ value of $x$ (storage period) that provides a reduction in the maximum value of the characteristic (y) by $50 \%$, that is, it corresponds to the storage periods at the inflection point of the curve.

\section{Results and Discussion}

The results obtained for the variables as a function of the two fruit collection areas and storage conditions of mandacaru seeds are presented in Table 1 . According to the variance analysis, there was a significant effect for the interaction between factors (Table 1 ) in all the evaluated characteristics, except for the package $\times$ storage period interaction in the normal seedling variable (NP) for seeds from the Caatinga area.

\section{Water content of seeds}

Before conducting the experimental trial, period zero, the water content of the seeds was around 14.4 and $13.5 \%$ for the seeds from the Caatinga and Atlantic Forest areas, respectively. Throughout storage, there was an oscillation in water content between 10.2 and $15.2 \%$ for seeds from the Caatinga area and between 7.8 and $15.1 \%$ for seeds from the Atlantic Forest area, according to the type of packaging and storage environment (Table 2).

\section{Seed germination}

Germination at the beginning of storage (period zero) was high (above 90\%) for both areas, but during storage, a decreasing behavior of this variable was observed for seeds stored at room temperature for both packages (Figures $3 \mathrm{~A}$ and $3 \mathrm{C}$ ). In this condition (room temperature), the reduction in the percentage of germination was even more accentuated for seeds stored in glass containers, especially for seeds in the Atlantic Forest area, whose germination percentage decreased by $50 \%$ of that obtained before storage (control), in just 135 days (Figure $3 \mathrm{C}$ ), as observed in the logistic equation. At six months, in the glass package, the percentage of germination was $7 \%$ (Figure $3 \mathrm{C}$ ). In the paper packaging, in the same area

Table 1. Analysis of variance for germination (G), germination speed index (GSI) and normal seedlings (NS) of Cereus jamacaru from stored seeds collected in areas of Caatinga and Atlantic Forest, following a factorial scheme: area $(A) \times$ package $(E) \times$ storage period $(P)$.

\begin{tabular}{|c|c|c|c|c|c|c|}
\hline \multirow{3}{*}{$\begin{array}{c}\text { Sources } \\
\text { of variation }\end{array}$} & \multicolumn{6}{|c|}{ Mean squares } \\
\hline & \multicolumn{3}{|c|}{ Caatinga } & \multicolumn{3}{|c|}{ Atlantic Forest } \\
\hline & $\mathbf{G}$ & GSI & NS & $\mathbf{G}$ & GSI & NS \\
\hline Area $(\mathrm{A})$ & $27270.0141^{* *}$ & $249.6150 * *$ & $27001.0417^{* *}$ & $43435.0417 * *$ & $393.3766^{* *}$ & $43265.0417^{* *}$ \\
\hline Packaging (E) & $570.3750 * *$ & $0.5104^{\text {ns }}$ & $145.0417^{* *}$ & $2625.0417^{* *}$ & $10.9958^{* *}$ & $2970.3750 * *$ \\
\hline Period (P) & $26561.2083 * *$ & $5.6022 * *$ & $4716.0417^{* *}$ & $6599.0417^{* *}$ & $5.2574 * *$ & $6220.5417^{* *}$ \\
\hline$A \times E$ & $234.3750 * *$ & $13.2017^{* *}$ & $234.3750 *$ & $1717.0417^{* *}$ & $3.4999 * *$ & $1162.0417^{* *}$ \\
\hline$A \times P$ & $29657.2083 * *$ & $37.2872 * *$ & $4918.4417^{* *}$ & $7152.0417^{* *}$ & $47.1567 * *$ & $6965.7417^{* *}$ \\
\hline$E \times P$ & $464.8750 * *$ & $20.4572 * *$ & $36.0417^{\text {ns }}$ & $575.0417 * *$ & $1.5397^{* *}$ & $562.6750 * *$ \\
\hline$A \times E \times P$ & $213.8750 * *$ & $14.4179 * *$ & $354.7750 * *$ & $634.0417^{* *}$ & $1.6525 * *$ & $370.7417^{* *}$ \\
\hline Average & 78.27 & 6.78 & 66.89 & 74.72 & 4.82 & 70.60 \\
\hline CV (\%) & 4.04 & 11.44 & 8.90 & 4.25 & 8.40 & 7.06 \\
\hline
\end{tabular}

$* *, *$ significant at $1 \%$ and $5 \%$ probability by the $\mathrm{F}$ test, respectively. ${ }^{\text {ns }}-$ not significant.

Table 2. Water content (\%) of mandacaru seeds from two ecosystems, packed in two packages and stored in two conditions of conservation for twelve months.

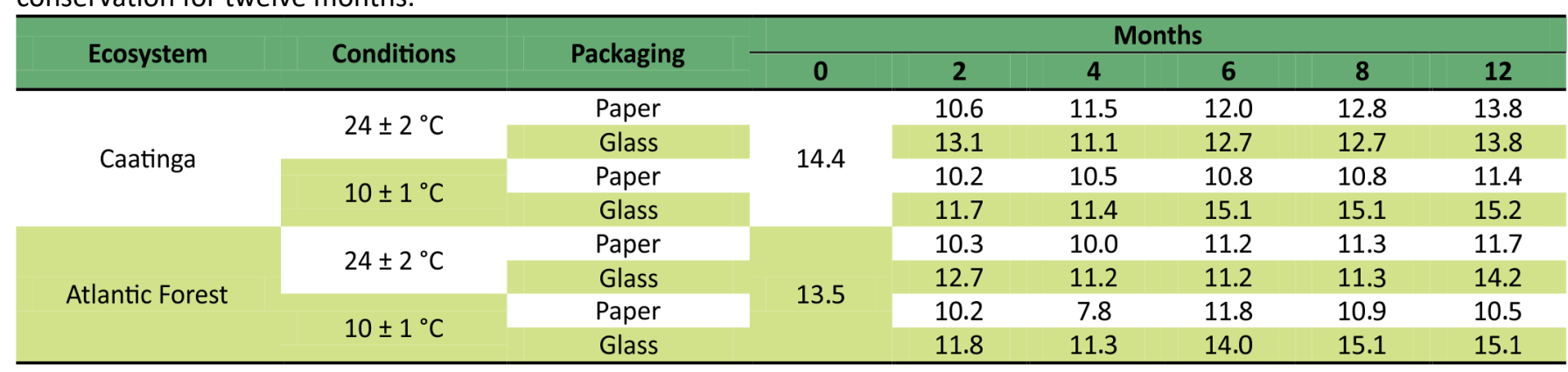



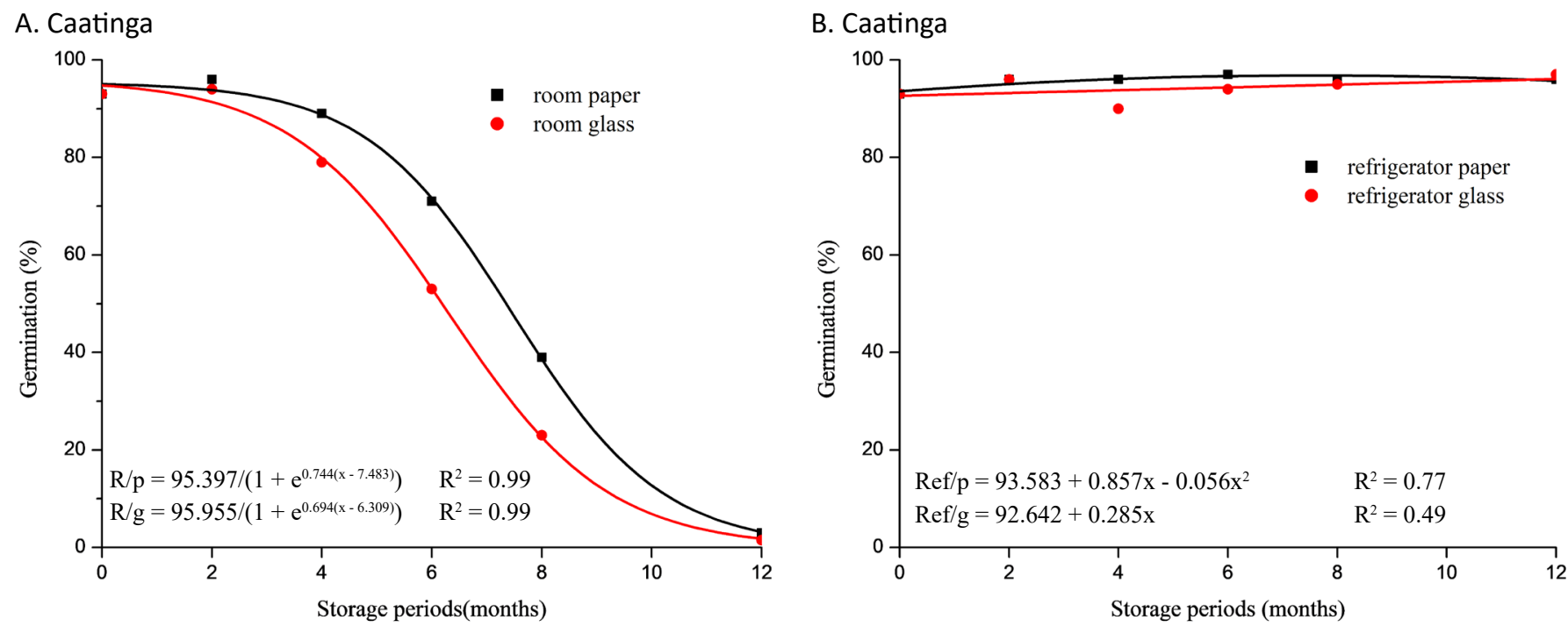

C. Atlantic Forest

D. Atlantic Forest
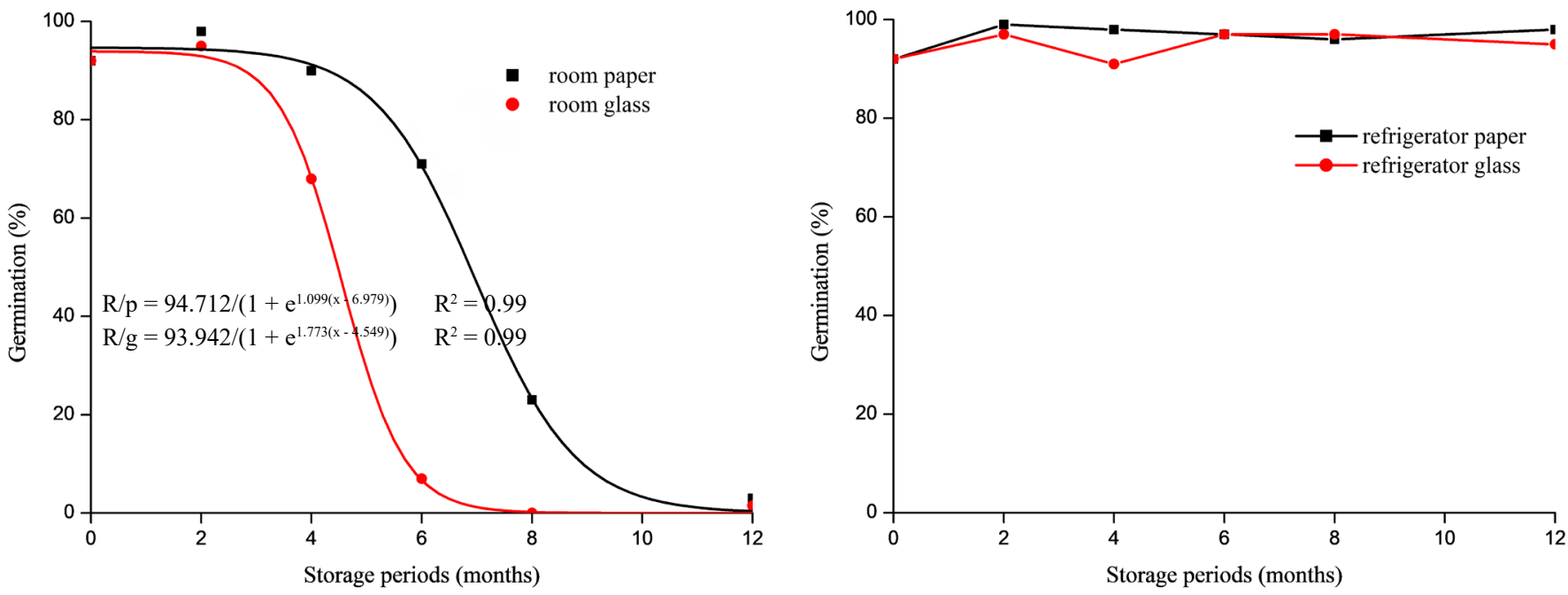

Figure 3. Percent germination of Cereus jamacaru seeds from two areas, stored in paper and glass containers and at room temperature and refrigerator for a period of twelve months. Caatinga - ambient (A); Caatinga - refrigerator (B); Atlantic Forest - ambient (C); Atlantic Forest - refrigerator (D).

(Atlantic Forest) (Figure 3C), although there were decreases in the physiological quality of the seeds, these losses were much smaller, because in the sixth month of storage, germination was above $70 \%$. While for seeds from the Caatinga area (Figure $3 \mathrm{~A})$, this decrease was smaller, since in the sixth month of storage, the germination percentage was around 50 and $70 \%$ for the glass and paper packages, respectively.

Regarding seeds stored in a refrigerator $\left(10 \pm 1{ }^{\circ} \mathrm{C} ; 43 \pm\right.$ $2 \% \mathrm{RH})$, it was observed that, regardless of the packaging, the germination percentage remained high, $\geq 90 \%$, throughout storage (Figures $3 \mathrm{~B}$ and $3 \mathrm{D}$ ). The germination percentages of seeds from the Caatinga area (Figure 3B) were adjusted to the quadratic (paper packaging) and linear (glass packaging) models, showing high germination percentages of mandacaru seeds throughout all storage periods. For the seeds from the Atlantic Forest area (Figure 3D), there was no significance in the data for the packages, which remained high for all periods. This germinal response can be explained by the reduction in seed metabolism and the degradation of storage compounds at lower temperatures (Santos et al., 2018). These results demonstrate that the refrigerator provided an adequate condition for the conservation of the seeds of this species when compared to room temperature, providing similar germination percentages over the twelve months of storage, regardless of the packaging.

Abud et al. (2012) when evaluating the physiological quality of seeds of xique-xique (Pilosocereus gounellei) in different packaging and storage environments, observed that storage in a cold chamber $\left(10{ }^{\circ} \mathrm{C} ; 60 \% \mathrm{RH}\right)$ was the most appropriate environment for seed storage, with the packaging of multiwall paper bag, plastic bag and glass being effective in maintaining physiological quality. However, at room temperature $\left(26.6^{\circ} \mathrm{C}\right.$; $76.9 \% \mathrm{RH})$, the use of paper packaging was the ideal storage condition for preserving the viability of seeds of this species for six months. These results are similar to those found in the present work with mandacaru seeds, because the seeds stored at room temperature in paper containers showed higher germination percentages in all storage periods when 
compared to those stored in glass containers, both for seeds from the Caatinga area (Figure 3A) and for seeds from the Atlantic Forest area (Figure 3C).

Probably, the initial water content of the seeds (13.5 and $14.4 \%$ ) caused greater degradation of the reserve compounds in those stored in glass containers, since the glass attenuated the exchange of gases and the loss of moisture with the external environment, unlike paper, thus reducing the physiological quality of the seeds. According to Marcos-Filho (2005), the water content of orthodox seeds generally should be between 10 and $12 \%$ for storage for six to eight months, with lower values indicated for species in which lipid reserves predominate, such as mandacaru seeds (Alencar et al. 2012). Seeds that contain high oil content have lower storage potential compared to those with starchy reserves, due to the lower chemical stability of lipids compared to starch (Taiz et al., 2017). Increased lipid peroxidation, membrane deterioration, increased free radicals, and reduced enzyme activity are primarily responsible at the cellular level for the reduction in seed viability (Graham, 2008).

Santos et al. (2018) observed that the seeds of Pilosocereus catingicola subsp. salvadorensis, P. gounellei subsp. gounellei, and Cereus fernambucensis subsp. fernambucensis preserved under cold chamber, freezer and liquid nitrogen conditions, had their germination equivalent to the control treatment (before storage). However, when the seeds of these taxa were stored at room temperature $\left(25-27^{\circ} \mathrm{C}\right)$, as the storage time increased, there was a drastic reduction in germinability, culminating in $0 \%$ after 13 months of storage, corroborating the results found in the present research with Cereus jamacaru. On the other hand, Rojas-Aréchiga et al. (2001), studying the germination of seeds of Stenocereus stellatus (Cactaceae) stored in paper bags at room temperature $(20 \pm$ $2{ }^{\circ} \mathrm{C}$ ), found that the germination of this species is $15 \%$ higher for seeds stored for 41 months than for seeds with six months of storage. In other words, depending on the cactus species, some may even increase their germination percentage as a function of storage, when stored under appropriate conditions, remaining viable for long periods and able to germinate and produce normal seedlings.

\section{Germination speed index}

As for the germination speed index, there was a decrease for this variable in seeds stored in the uncontrolled environment conditions (Figures $4 \mathrm{~A}$ and $4 \mathrm{C}$ ), in both packages, especially in those conditioned in the glass container, regardless of the area. In an uncontrolled environment (Figures $4 \mathrm{~A}$ and $4 \mathrm{C}$ ), the GSI of seeds stored on paper in the sixth month was 4.95 and 3.66 for seeds from the Caatinga and Atlantic Forest areas, respectively. While in glass containers the average value was 3.33 (Caatinga) and 0.38 (Atlantic Forest). The highest GSI values were observed in seeds stored in a cooled environment (refrigerator), regardless of the packaging, in all storage periods. Low germination speed is one of the indications of lower physiological potential, being one of the most evident manifestations of the deterioration process (Marcos-Filho, 2005).
Importantly, the initial (control) GSI was 7.52 (Caatinga) and 5.30 (Atlantic Forest). At 12 months of refrigerator storage, for the seeds from the Caatinga area (Figure 4B), this initial index increased to 9.52 (paper) and 9.59 (glass); whereas, Atlantic Forest seeds (Figure 4D) showed values of 8.44 (paper) and 8.07 (glass). These data show the importance of preserving seeds under conditions of low temperature and air humidity because they are conditions that promote low seed metabolism, prolonging their germination potential for longer periods and also improving the physiological quality of the seeds of mandacaru during storage.

Under conditions of higher temperatures and high $\mathrm{RH}$, the seeds, in the case of cactaceae, in general, cannot maintain high germinability and vigor because such conditions allow the seeds metabolism to accelerate more rapidly, leading to a deterioration process. This factor alters the biochemical and physiological processes, increasing the degradation of reserve material, reducing germination and vigor of seeds stored in inadequate conditions for their conservation, because during deterioration there is the production of reactive oxygen species, which alter the structure of antioxidant enzymes, causing a more pronounced decrease in seed viability, while in favorable conditions, with low temperatures, the speed of chemical reactions, and consequently respiration, are reduced, favoring the conservation of seeds for longer periods (Marcos-Filho, 2005; Graham, 2008).

Silva et al. (2018), evaluating the germination of two cactaceous species, Melocactus bahiensis and Harrisia adscendens, found that storage for seven years in cold storage maintained the physiological quality of the seeds of both species. In addition, the authors also verified that there was an increase in the germination percentage and GSI of stored seeds compared to freshly collected ones, both for $M$. bahiensis and $H$. adscendens. After being stored in low temperature conditions, seeds of some cactus species can germinate significantly faster than seeds not stored or stored at room temperature, for example seeds of $M$. sergipensis and M. zehntneri when stored in cold room and freezer (Santos et al., 2018).

According to Abud et al. (2016) mandacaru seeds can remain viable for six months when stored in cold storage. But in a natural environment, storage in permeable packaging (paper) for up to six months is recommended, as high germination and GSI rates were observed when compared to seeds stored in plastic and glass packaging. These results corroborate those found in this research, since the seeds stored at room temperature in paper containers showed greater vigor throughout storage compared to those stored in glass containers, regardless of the origin of the seeds.

In this same perspective, Nascimento \& Meiado (2016) when studying the viability of Discocactus bahiensis seeds stored in a cold chamber (ex situ conservation) and in the soil in an area of natural occurrence of the species (in situ conservation), found that during the first ten months of storage the germination of seeds conserved in situ and 
A. Caatinga

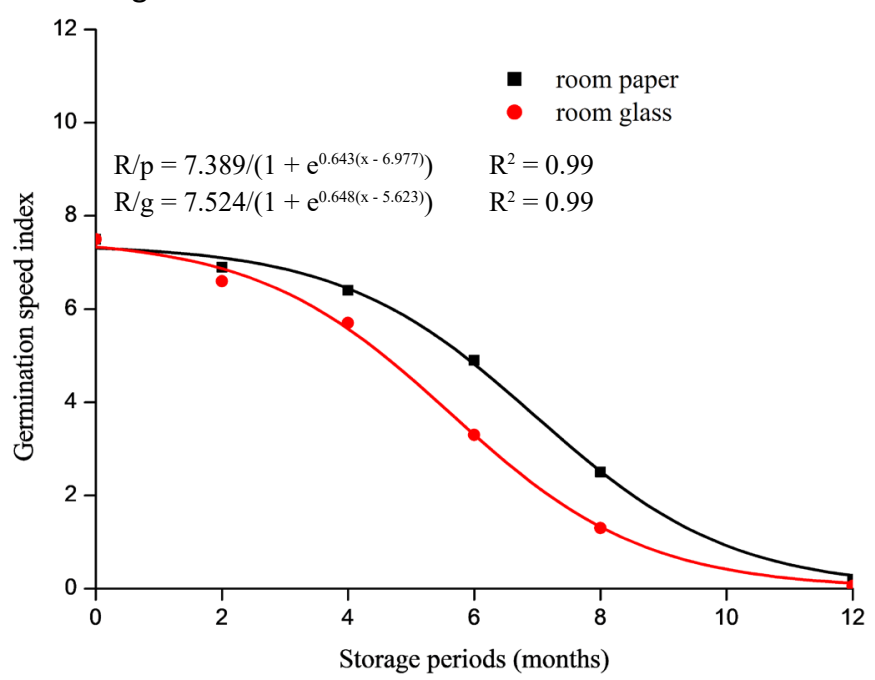

C. Atlantic Forest

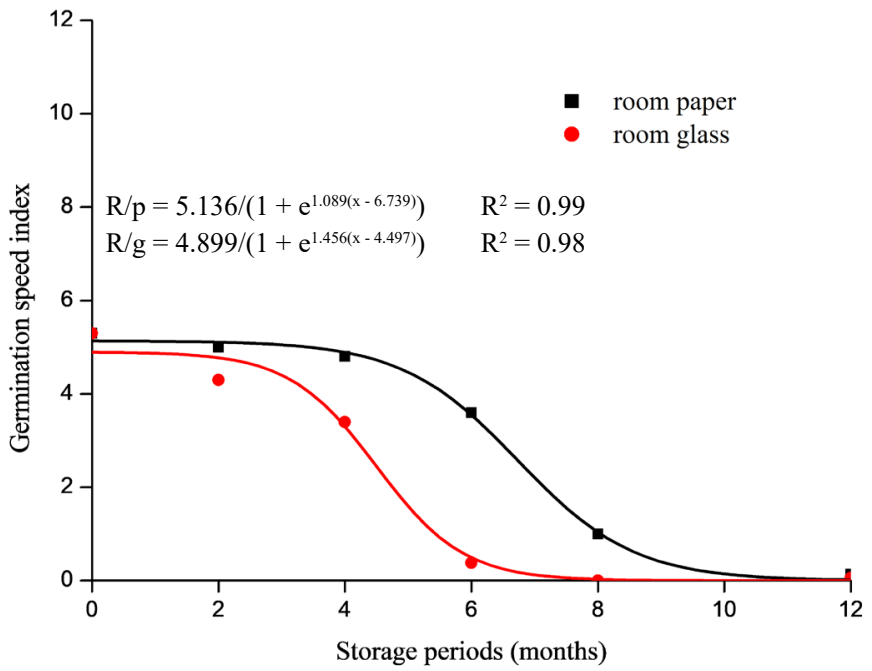

B. Caatinga

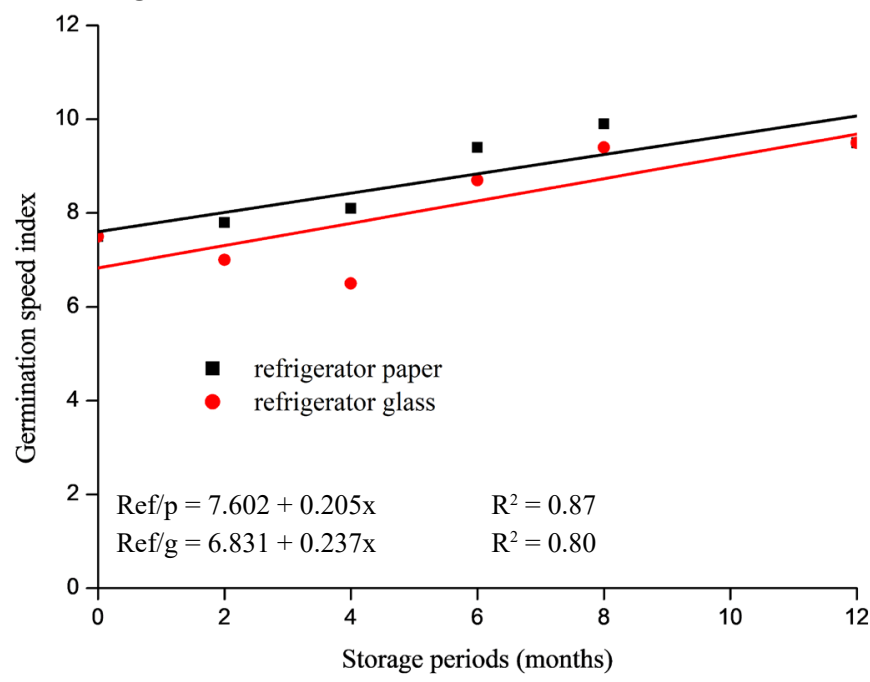

D. Atlantic Forest

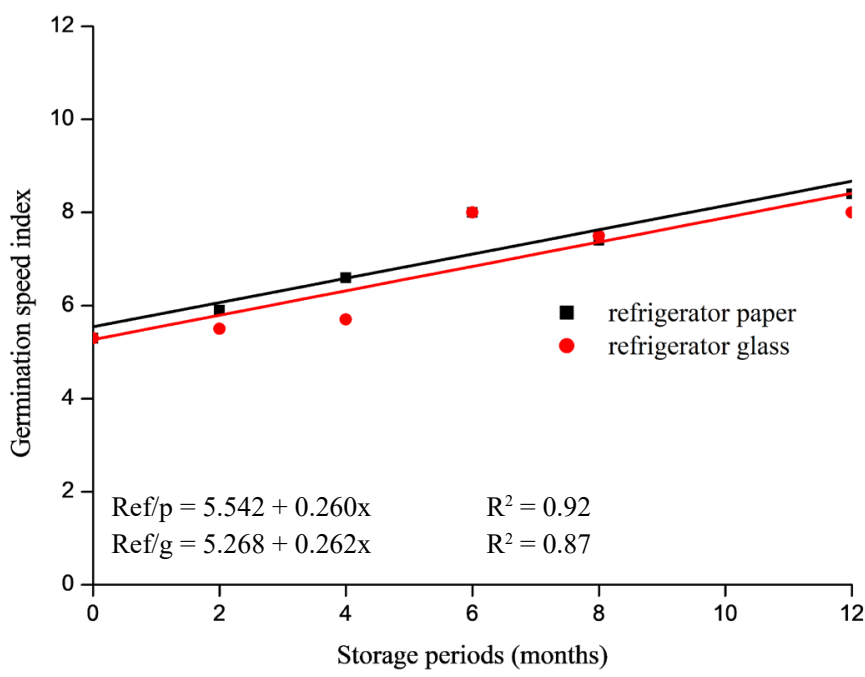

Figure 4. Germination speed index (GSI) of Cereus jamacaru seeds from two areas, stored in paper and glass packages and at room temperature and refrigerator for a period of twelve months. Caatinga - room (A); Caatinga - refrigerator (B); Atlantic Forest - room (C); Atlantic Forest - refrigerator (D).

ex situ were similar. After this period, a $70 \%$ reduction in germinability of seeds kept in the field was observed, and there was an almost complete loss of viability after 12 months of storage. On the other hand, the seeds stored in cold storage maintained germinability higher than $70 \%$ throughout storage, demonstrating that ex situ conservation is the most efficient way to maintain seed viability in this endangered species.

\section{Normal seedlings}

As for the percentage of normal seedlings (Figures $5 \mathrm{~A}$ and $5 \mathrm{C})$, it was found that, as the storage time in room temperature conditions was prolonged, there was a reduction in the percentage of these seedlings, in a more accentuated way, in the glass, for the two collection areas. In this condition, the seeds from the Atlantic Forest area exhibited, at six months, a percentage of normal seedlings of $60 \%$ in the paper package and below $10 \%$ in the glass package (Figure $5 \mathrm{C}$ ). When the seeds were stored in refrigerator (Figures 5B and 5D), high percentages of normal seedlings (> 70\%) were observed throughout the storage period, regardless of packaging and/ or area. In the case of seeds from the Caatinga area (Figure $5 B)$, the data were not significant according to the Anova (Table 1) for the two packages, however, according to the values observed, despite some fluctuations, it was observed that these were above $70 \%$. For the Atlantic Forest seeds (Figure 5D), the data fitted an increasing linear equation for the paper package and a quadratic equation for the glass package, showing high percentages of normal seedlings during storage.

Due to the ecological and sociocultural importance of cacti and the high number of endangered species, new studies on this topic should be encouraged, especially taking into account species that have never been evaluated and about which nothing is known about their germination behavior (Meiado et al., 2017). According to these authors, such studies can serve as a basis for projects aimed at ex situ conservation, the creation of germplasm banks, seedling production, species recomposition and the enrichment of degraded areas and, in 

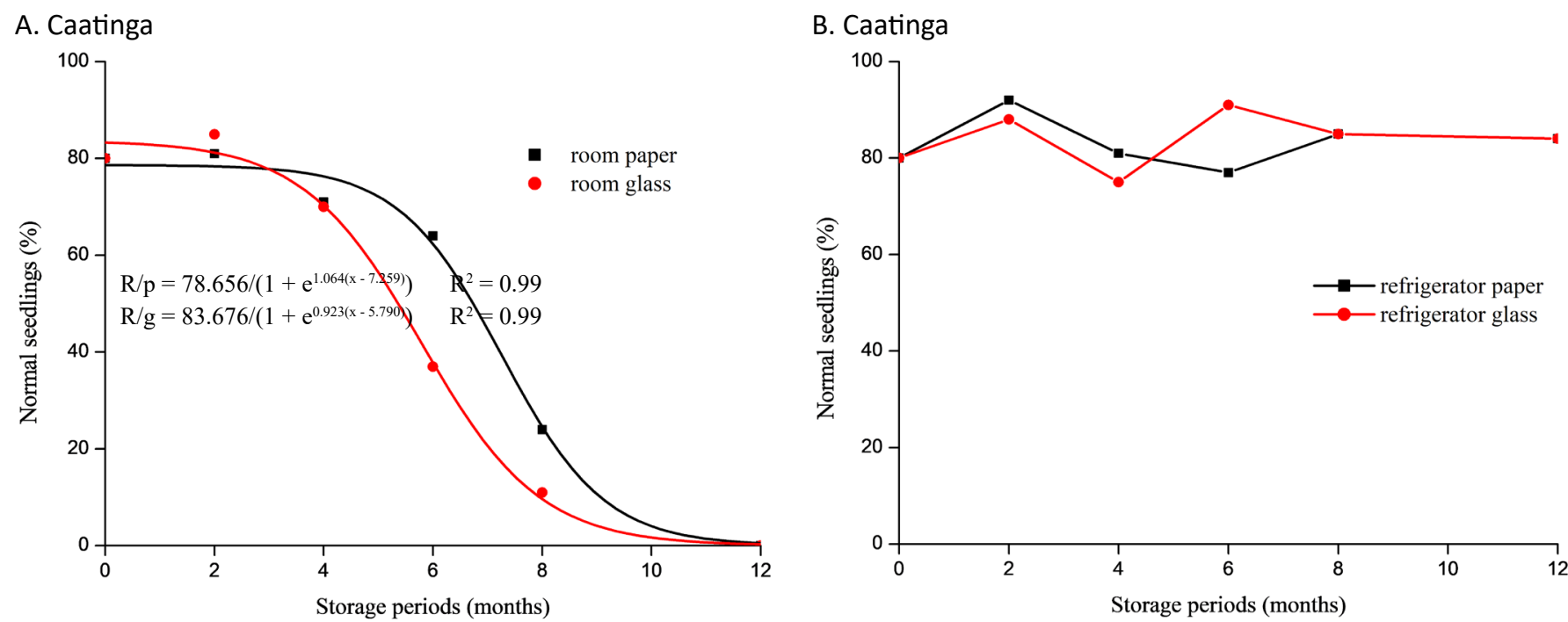

C. Atlantic Forest

D. Atlantic Forest
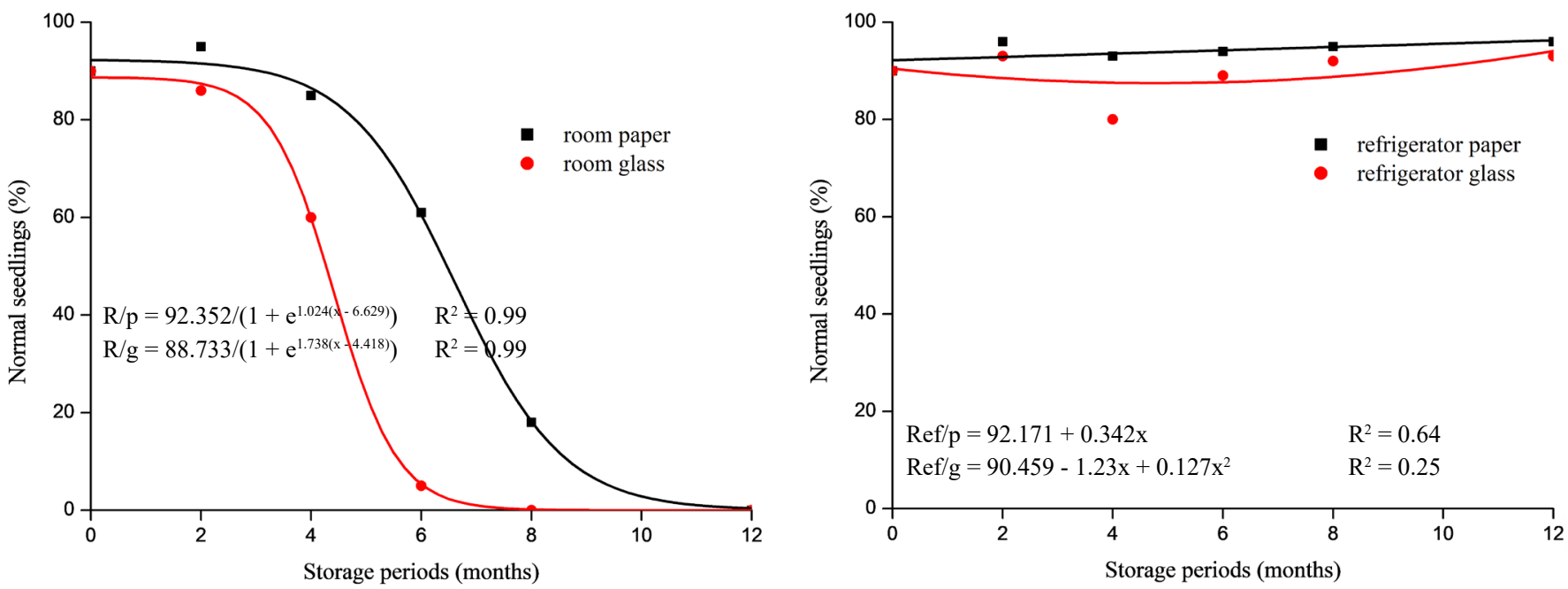

Figure 5. Percentage of normal seedlings of Cereus jamacaru from two areas, stored in paper and glass containers and at room temperature and refrigerator for a period of twelve months. Caatinga - room (A); Caatinga - refrigerator (B); Atlantic Forest room (C); Atlantic Forest - refrigerator (D).

the case of this work, that these results serve as a subsidy for the preservation of these ecosystems located in Paraíba and in the state of Pernambuco.

\section{Conclusions}

There was a reduction in germination and vigor of Cereus jamacaru DC. seeds kept at room temperature throughout storage, regardless of the area of origin of the fruit and the packaging.

Paper packaging was more efficient than glass when the seeds were stored at room temperature.

Refrigerated storage of mandacaru seeds favored seed germination and vigor, regardless of the packaging.

\section{Acknowledgments}

To Daniel da Silva Gomes for the elaboration of the map of location of the areas. To the Center of Human, Social and
Agrarian Sciences and the Pro-Rectorate of Research of the Universidade Federal da Paraíba for the research scholarship granted to the first author.

\section{Compliance with Ethical Standards}

Author contributions: Conceptualization: GAA; Data curation: VAT, JHCSS; Formal analysis: GAA; Funding acquisition: GAA; Investigation: VAT, JHCSS; Methodology: GAA, VAT; Project administration: GAA; Resources: GAA, VCS; Supervision: GAA; Validation: VAT, GAA, JHCSS, VCS; Visualization: VAT, GAA, JHCSS, VCS; Writing - original draft: VAT, JHCSS; Writing - review \& editing: GAA, VCS.

Conflict of interest: The authors declare that there are no conflicts of interest.

Financing source: The research grant to the first author was financed by the Pró-Reitoria de Pesquisa of the Universidade Federal da Paraíba (PROPESQ). 


\section{Literature Cited}

Abud, H.F.; Pereira, D.S.; Gonçalves, N.R; Pereira, M.S.; Bezerra, A.M.E. Armazenamento de sementes de xique-xique. Revista Brasileira de Sementes, v.34, n.3, p.473-479, 2012. https://doi. org/10.1590/S0101-31222012000300015.

Abud, H.F.; Pereira, M.S.; Pereira, D.S.; Gonçalves, N.R.; Bezerra, A.M.E. Physiological quality of Mandacaru seeds stored in different environments and packages. International Journal of Current Research, v.8, n.2, p.26503-26507, 2016. https://www. journalcra.com/sites/default/files/issue-pdf/12999.pdf. 23 Sep. 2020.

Alencar, N.L.; Innecco, R.; Gomes-Filho, E.; Gallão, M.I.; AlvarezPizarro, J.C.; Prisco, J.T.; Oliveira, A.B.D. Seed reserve composition and mobilization during germination and early seedling establishment of Cereus jamacaru DC ssp. jamacaru (Cactaceae). Anais da Academia Brasileira de Ciências, v. 84 n.3, p.823-832, 2012. https://doi.org/10.1590/S0001-37652012000300024.

Brasil. Ministério da Agricultura, Pecuária e Abastecimento. Regras para análise de sementes. Ministério da Agricultura, Pecuária e Abastecimento. Secretaria de Defesa Agropecuária. Brasília: MAPA; ACS, 2009. 395p.

Gomes, G.R. Família Cactaceae: Breve revisão sobre sua descrição e importância. Revista Técnico Científica, v.1, n.2, p.1-10, 2014. http://creaprw16.creapr.org.br/revista/Sistema/index.php/ revista/article/view/38/26. 06 Sep. 2020.

Gomes, V.G.N.; Cassimiro, C.A.L.; Freitas, J.G.; Felix, C.M.P.; Batista, F.R.C. Ex situ conservation in the Brazilian semiarid: Cactaceae housed in the collection of the Guimarães Duque Cactarium. Brazilian Journal of Development, v.6, n.8, p.6260862625, 2020. https://doi.org/10.34117/bjdv6n8-626.

Graham, I.A. Seed storage oil mobilization. Annual Review of Plant Biology, v.59, p.115-142, 2008. http://doi:10.1146/annurev. arplant.59.032607.092938.

Hoppe, J.M. (Org.). Produção de sementes e mudas florestais. 2.ed. Santa Maria: UFSM, 2004. 388p. (UFSM, Programa de Pós-Graduação em Engenharia Florestal. Caderno didático, v.1, n.2). http://www.faesb.edu.br/biblioteca/wp-content/ uploads/2017/09/livro_producao_de_sementes_e_mudas_ florestais1.pdf. 20 Jul. 2020.

Maguire, J.O. Speed of germination and in selection and evaluation for seedling emergence and vigor. Crop Science, v.2, n.2, p.176177, 1962. https://doi.org/10.2135/cropsci1962.0011183X0002 $00020033 x$

Marcos-Filho, J. Fisiologia de sementes de plantas cultivadas. Piracicaba: FEALQ, 2005. 495p.
Meiado, M.V.; Lima, A.T.; Nascimento, J.P.B.; Aona, L.Y.S. Avanços nos estudos sobre sementes e plântulas de cactos do Brasil. Gaia Scientia, v.11, n.4, p.88-113, 2017. https://doi.org/10.22478/ ufpb.1981-1268.2017v11n4.35473.

Menezes, M.O.T.; Ribeiro-Silva, S. Cactáceas do Ceará, Brasil: prioridades para a conservação. Gaia Scientia, v.9, n.2, p.67-76. 2015. https://periodicos.ufpb.br/ojs2/index.php/gaia/article/ download/24166/13265/. 09 Sep. 2020.

Nascimento, J.P.B.; Meiado, M.V. In situ or ex situ seed conservation: which is the more effective way to maintain seed longevity of an endangered cactus? Plant Species Biology, v.32, n.2, p.115-120, 2016. https://doi.org/10.1111/1442-1984.12131.

Oliveira, D.M.; Lima, A.T.L.; Rocha, E.A.; Meiado, M.V. O aumento da temperatura reduz a tolerância ao estresse hídrico na germinação de sementes de Pereskia grandifolia Haw. subsp. grandifolia (Cactaceae). Gaia Scientia, v.11, n.4, p.26-36, 2017. https://doi org/10.22478/ufpb.1981-1268.2017v11n4.35466.

Pôrto, D.R.Q.; Cecílio, F.A.B.; May, A.; Barbosa, J.C. Acúmulo de macronutrientes pela cebola "Optima" estabelecida por semeadura direta. Horticultura Brasileira, v.24, n.4, p.470-475, 2006. https://doi.org/10.1590/S0102-05362006000400015.

Rojas-Aréchiga, M.; Casas, A.; Vázquez-Yanes, C. Seed germination of wild and cultivated Stenocereus stellatus (Cactaceae) from the Tehuacán-Cuicatlán Valley, Central México. Journal of Arid Environments, v.49, n.2, p.279-287, 2001. https://doi. org/10.1006/jare.2001.0789.

Santos, A.P.; Hassemer, G.; Meiado, M.V. Seed storage of Brazilian cacti species in different threat categories. Plant Species Biology, v.33, n.3, p.203-211, 2018. https://doi.org/10.1111/14421984.12208.

Silva, R.C.S.; Amariz, A., Kiill, L.H.P. Influência da temperatura e do tempo de armazenamento na germinação de sementes de duas espécies de cactáceas. Informativo Abrates, v.28, n.1, p.97-101, 2018. https://www.alice.cnptia.embrapa.br/handle/ doc/1109064. 23 Sep. 2020.

Silva, S.R.; Zappi, D.C.; Taylor, N.; Machado, M.C. (Orgs.). Plano de ação nacional para conservação das cactáceas. Brasília: Instituto Chico Mendes de Conservação da Biodiversidade, Brasil, 2011. 112p. (ICMBIO. Série Espécies Ameaçadas, v.24).

Taiz, L.;Zeiger, E.; Møller, I.M.; Murphy, A. Fisiologia e desenvolvimento vegetal. 6.ed. Porto Alegre: Artmed Editora, 2017. 858p.

Zappi, D.; Taylor, N. Cactaceae. In: Lista de Espécies da Flora do Brasil. Jardim Botânico do Rio de Janeiro. 2020. http://floradobrasil.jbrj. gov.br/reflora/floradobrasil/FB70. 27 Feb. 2021. 